\title{
PERSENTASE TUTUPAN DAN STRUKTUR KOMUNITAS MANGROVE DI SEPANJANG PESISIR TAMAN NASIONAL BUNAKEN BAGIAN UTARA
}

\section{(The Percentage of Cover and Mangrove Community Structure at Northern Bunaken National Park Shoreline)}

\author{
Annice Anthoni ${ }^{1 *}$, Joshian N.W. Schaduw ${ }^{1}$, Calvyn F.A. Sondak ${ }^{1}$
}

1. Program Studi IImu Kelautan Fakultas Perikanan dan IImu Kelautan Universitas Sam

Ratulangi, Manado.

*e-mail : anniceanthoni@gmail.com

The purposes of this study are to calculate the percentage of mangrove cover and to know the structure of the mangrove community. This research was conducted along the coast of North Bunaken National Park. The method used in this research was line transect method and hemisperichal photography method. The results of the study were 6 species of mangroves, Sonneratia alba, Avicennia officinalis, Avicennia marina, Rhizophora apiculata, Rhizophora mucronata and Bruguiera gymnorrhiza belonging to 4 families of Sonneratiaceae, Avicenniaceae, Rhizophoraceae and Bruguieraceae. The highest canopy mangrove cover value at station 2 (Meras) in transect 2 reached $82.78 \%$ and the lowest at station 1 (Molas) in transect 1 was $61.24 \%$.

Keywords : percentage cover, mangrove, community

Tujuan dari penelitian ini adalah menghitung persentase tutupan mangrove dan mengetahui struktur komunitas mangrove. Penelitian ini dilakukan di sepanjang pesisir Taman Nasional Bunaken bagian Utara. Metode yang di gunakan dalam penelitian ini yaitu metode line transect dan metode hemisperichal photography. Data hasil penelitian ditemukan 6 jenis mangrove yaitu Sonneratia alba, Avicennia officinalis, Avecennia marina, Rhizophora apiculata, Rhizophora mucronata dan Bruguiera gymnorrhiza yang termasuk dalam 4 famili Sonneratiaceae, Avicenniaceae, Rhizophoraceae dan juga Bruguieraceae. Nilai tutupan kanopi mangrove yang tertinggi pada stasiun 2 (Meras) di transek 2 mencapai nilai 82,78\% dan yang terendah pada stasiun 1 (Molas) di transek 1 yaitu 61,24\%.

Kata Kunci : persentase tutupan, mangrove, komunitas

\section{PENDAHULUAN}

Taman Nasional Bunaken merupakan perwakilan ekosistem perairan tropis di Indonesia yang terdiri dari ekosistem mangrove, padang lamun, terumbu karang, dan ekosistem daratan atau pesisir. Secara geografis Taman Nasional ini terletak di Provinsi Sulawesi Utara dengan luas kawasan $89.065 \mathrm{Ha}$, yang dibagi menjadi dua bagian, yaitu bagian Utara dan bagian Selatan. Bagian Utara kepulauan meliputi Pulau Bunaken, Pulau Manado Tua, Pulau Siladen, Pulau Mantehage,
Pulau Nain dan daerah bagian daratan pesisir utara yaitu desa Molas, desa Meras, desa Tongkaina, desa Tiwoho, sedangkan bagian Selatan mulai dari desa Poopoh sampai ke desa Popareng (Arakan - Wawontulap) (Metha, 1999). Menurut Kaunang \& Kimbal (2009), Taman Nasional Bunaken merupakan kawasan pelestarian alam yang mempunyai fungsi untuk perlindungan ekosistem penyangga kehidupan, konservasi jenis tumbuhan dan satwa, serta pemanfaatan secara lestari sumberdaya alam hayati dan 
ekosistemnya. Mangrove merupakan salah satu ekosistem di Taman Nasional Bunaken yang memiliki keanekaragaman hayati yang tinggi dengan luas total sekitar 1.800 Ha yaitu $20 \%$ terdiri dari hutan bakau dengan rincian mengelilingi Pulau Mantehage $( \pm 1.435 \mathrm{Ha})$, Pulau Bunaken $( \pm 75 \mathrm{Ha})$, Pulau Manado Tua $( \pm 7,7 \mathrm{Ha})$, Pulau Siladen dan Pulau Nain $( \pm 7 \mathrm{Ha})$. Di pesisir bagian utara Malalayang dan Wori 235 Ha dan Arakan Wawontulap seluas $933 \mathrm{Ha}$ (Anonimous, 2005 dalam Pontoh, 2011).

Potensi hutan mangrove yang terdapat di sepanjang pesisir Taman Nasional Bunaken bagian utara merupakan salah satu aset yang penting untuk dijaga dan dilestarikan. Hutan mangrove dapat dikembangkan menjadi suatu kawasan yang menguntungkan baik dalam segi ekologis maupun segi ekonomis. Maka dalam upaya pengelolaan dan pelestarian sumberdaya mangrove dibutuhkan adanya kegiatan penelitian yang dapat memberikan informasi ilmiah tentang keadaan atau kondisi terkini dari lokasi tersebut.

Tujuan dari penelitian ini untuk menghitung persentase tutupan mangrove dan mengetahui struktur komunitas mangrove yang meliputi kerapatan jenis, kerapatan relatif jenis, frekuensi jenis, frekuensi relatif jenis, penutupan jenis, penutupan relatif jenis, indeks nilai penting, indeks keanekaragaman jenis, dan indeks kemerataan jenis. Sedangkan manfaat dari penelitian ini dapat memberikan informasi ilmiah, dapat menjadi acuan kebijakan Pemerintah Kota Manado dalam rencana pengembangan wilayah dan konservasi dan dapat menjadi data yang bisa membantu penelitianpenelitian selanjutnya.

\section{METODE PENELITIAN}

\section{Tempat dan Waktu}

Penelitian ini dilakukan di sepanjang pesisir Taman Nasional Bunaken bagian Utara yaitu desa
Tabel 1. Alat dan bahan penelitian

\begin{tabular}{|c|c|c|}
\hline 0 & $\begin{array}{l}\text { Alat dan } \\
\text { Bahan }\end{array}$ & Kegunaan \\
\hline 1 & $\begin{array}{l}\text { Bahan } \\
\text { identifikasi } \\
\text { mangrove }\end{array}$ & $\begin{array}{l}\text { Pedoman jenis-jenis } \\
\text { mangrove }\end{array}$ \\
\hline 2 & GPS & $\begin{array}{l}\text { Merekam titik } \\
\text { koordinat geografis }\end{array}$ \\
\hline 3 & Kamera & Dokumentasi \\
\hline 4 & Tali Plastik & $\begin{array}{l}\text { Membentuk transek } \\
\text { wilayah }\end{array}$ \\
\hline 5 & $\begin{array}{l}\text { Meteran } \\
\text { Rol }\end{array}$ & $\begin{array}{l}\text { Mengukur panjang } \\
\text { transek }\end{array}$ \\
\hline 6 & $\begin{array}{l}\text { Meteran } \\
150 \mathrm{~cm}\end{array}$ & $\begin{array}{l}\text { Mengukur keliling } \\
\text { lingkar batang pohon }\end{array}$ \\
\hline 7 & Pilox & Membuat tanda \\
\hline 8 & Alat Tulis & $\begin{array}{l}\text { Mencatat data hasil } \\
\text { penqukuran }\end{array}$ \\
\hline
\end{tabular}

Molas, desa Meras, desa Tongkaina, desa Bahowo dan desa Tiwoho. Waktu pelaksanaan penelitian ini adalah pada tanggal 13 hingga 19 Maret 2017.

Metode yang digunakan dalam kegiatan penelitian ini yaitu line transect yang dilakukan dengan cara membuat garis tegak lurus pantai ke arah darat dengan membuat petakan atau plot-plot (Cox, 1969 dalam Abrar et al., 2014) untuk mengetahui struktur komunitas mangrove. Selanjutnya, metode hemisperichal photography adalah teknik karakteristik kanopi dengan menggunakan foto-foto dalam memperkirakan radiasi matahari dan ciri tanaman melalui lensa pandang jauh (Anderson, 1964) untuk mengetahui persentase tutupan mangrove.

\section{HASIL DAN PEMBAHASAN}

\section{Jenis-Jenis Mangrove}

Berdasarkan hasil penelitian yang dilakukan pada kelima stasiun ditemukan 6 spesies mangrove yaitu Sonneratia alba, Avicennia officinalis, Avicennia marina, Rhizophora apiculata, Rhizophora mucronata dan Bruguiera gymnorrhiza yang termasuk dalam 4 famili Sonneratiaceae, Avicenniaceae, Rhizophoraceae dan Bruguieraceae. Jenis mangrove yang 
paling umum ditemukan pada setiap stasiun penelitian yaitu Sonneratia alba. Menurut Sofian et al. (2012) jenis ini memiliki keunggulan dalam menyesuaikan diri dengan kondisi lingkungan

\section{Persentase Tutupan Mangrove}

Berdasarkan hasil analisis
dengan menggunakan metode hemisperichal photography bahwa tutupan kanopi mangrove dari kelima stasiun di sepanjang pesisir Taman Nasional Bunaken memiliki hasil yang berbeda. Pada stasiun 1 (Molas) di transek 1 dengan nilai $61,24 \%$ dan di transek 2 yaitu $69,21 \%$, sehingga ditinjau dari Kepmen LH No 201 Tahun 2004 tentang kriteria kerusakan mangrove termasuk pada kategori sedang dengan nilai tutupan kanopi mangrovenya yaitu $>75 \%$. Pada stasiun 2 (Meras) di transek 1 dengan nilai $76,44 \%$ dan di transek 2 yaitu $82,78 \%$, ditinjau dari Kepmen LH No 201 Tahun 2004 tentang kriteria kerusakan mangrove termasuk pada kategori sangat padat dengan nilai tutupan kanopi mangrovenya yaitu $\geq 75 \%$. Pada stasiun 3 (Tongkaina) di transek 1 dengan nilai $65,77 \%$ dan di transek 2 yaitu $76,20 \%$, sehingga ditinjau dari Kepmen LH No 201 Tahun 2004 tentang kriteria kerusakan mangrove termasuk pada kategori sedang $75 \%$ dan sangat padat $\geq 75 \%$. Pada stasiun 4 (Bahowo) di transek 1 dengan nilai $67,88 \%$ dan di transek 2 yaitu $80,79 \%$, sehingga ditinjau dari Kepmen LH No 201 Tahun 2004 tentang kriteria kerusakan mangrove termasuk pada kategori sedang $75 \%$ dan sangat padat $\geq 75 \%$. Kemudian pada stasiun 5 (Tiwoho) di transek 1 dengan nilai $67,67 \%$ dan di stransek 2 yaitu $76,70 \%$, sehingga ditinjau dari Kepmen LH No 201 Tahun 2004 tentang kriteria kerusakan mangrove termasuk pada kategori sedang $75 \%$ dan sangat padat $\geq 75 \%$.

\section{Struktur Komunitas Mangrove Kerapatan jenis dan Kerapatan relatif jenis}

Nilai tertinggi kerapatan jenis pada stasiun 1 (Molas) di transek 1 adalah S.alba yaitu 0,130 , terendah di transek 1 oleh A.officinalis yaitu 0,043, sedangkan nilai kerapatan relatifnya yaitu 75,00 dan 25,00 . Nilai tertinggi kerapatan jenis pada stasiun 2 (Meras) di transek 2 adalah A.officinalis yaitu 0,060, terendah di transek 1 oleh A.officinalis yaitu 0,003 , sedangkan nilai kerapatan relatifnya yaitu 64,29 dan 7,143. Nilai tertinggi kerapatan jenis pada stasiun 3 (Tongkaina) di

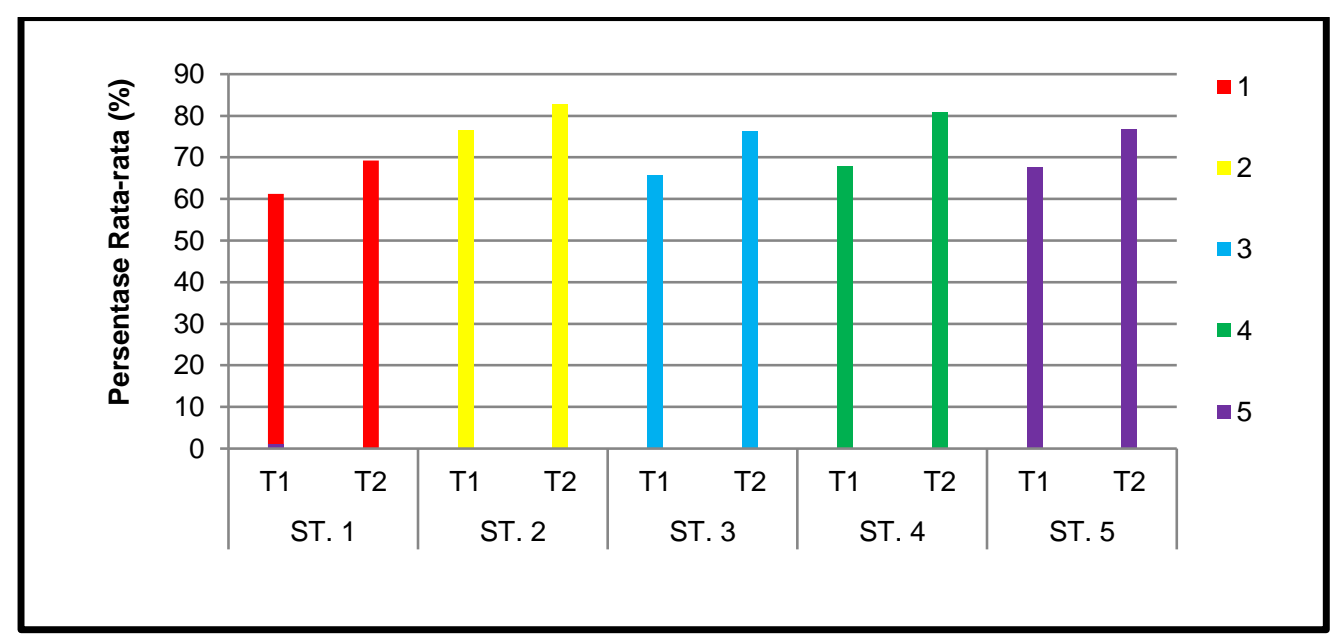

Gambar 1. Persentase tutupan kanopi mangrove (Ket : ST : Stasiun, T : Transek) 


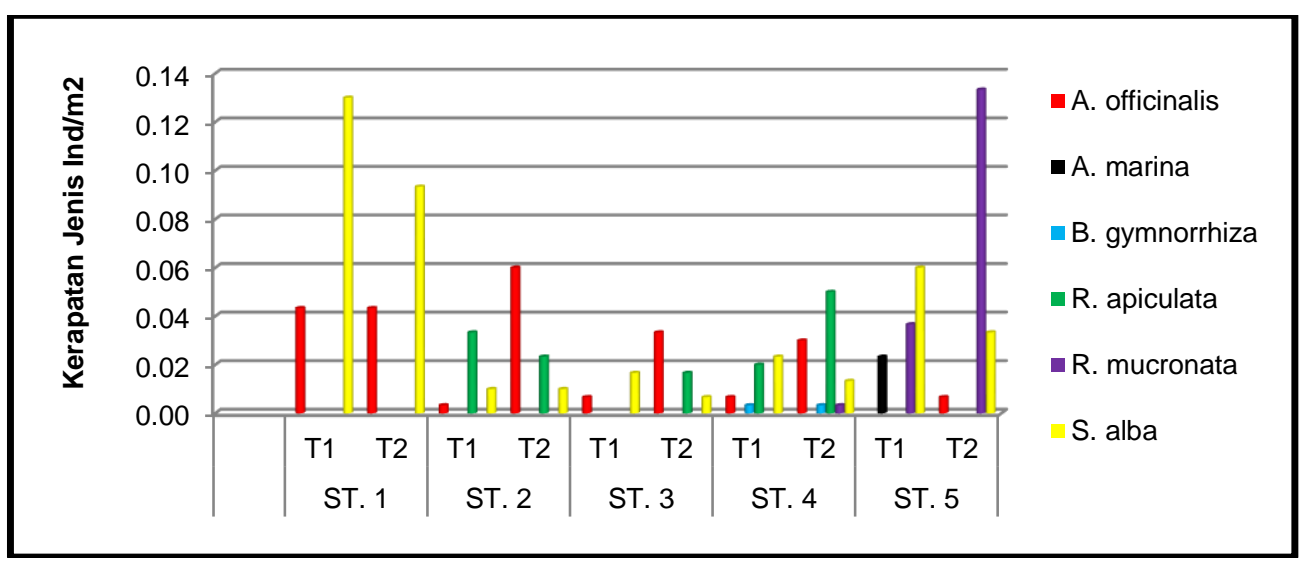

Gambar 2. Kerapatan jenis (Ket : ST : Stasiun, T : Transek)

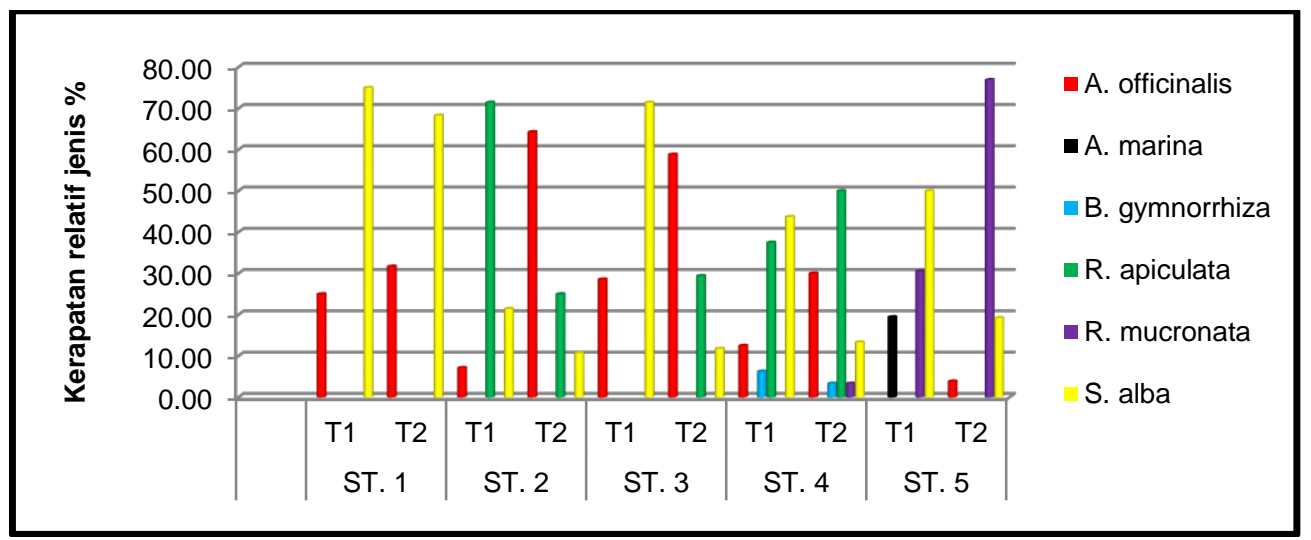

Gambar 3. Kerapatan relatif jenis (Ket : ST : Stasiun, T : Transek)

transek 2 adalah A.officinalis yaitu 0,033, terendah di transek 2 oleh S.alba yaitu 0,007 , sedangkan nilai kerapatan relatifnya yaitu 58,82 dan 11,76. Nilai tertinggi kerapatan jenis pada stasiun 4 (Bahowo) di transek 2 adalah $R$.apiculata yaitu 0,050, terendah di transek 2 oleh B.gymnorrhiza dan R.mucronata yaitu 0,003, sedangkan nilai kerapatan relatifnya yaitu 50,00 dan 3,333 . Nilai tertinggi kerapatan jenis pada stasiun 5 (Tiwoho) di transek 2 adalah R.mucronata yaitu 0,133 , terendah di transek 2 yaitu A.officinalis yaitu 0,007, sedangkan nilai kerapatan relatifnya yaitu 76,92 dan 3,846 .

Kerapatan jenis tertinggi disebabkan oleh subsrat yang cocok, dan kemampuan beradaptasi dengan kondisi lingkungan. Faktor yang menyebabkan pertumbuhan mangrove relatif jarang adalah kondisi akar pohon yang tergolong besar sehingga pertumbuhan mangrove tersebut menjadi kurang optimal (Agustini et al.,. 2016).

\section{Frekuensi Jenis dan Frekuensi Relatif Jenis}

Nilai tertinggi frekuensi jenis pada stasiun 1 (Molas) di transek 1 dan 2 adalah A.officinalis yaitu 0,667, terendah di transek 1 dan 2 oleh S.alba yaitu 0,333 , sedangkan nilai frekuensi relatif yaitu 66,67 dan 33,33 . Nilai tertinggi frekuensi jenis pada stasiun 2 (Meras) di transek 1 dan 2 adalah 


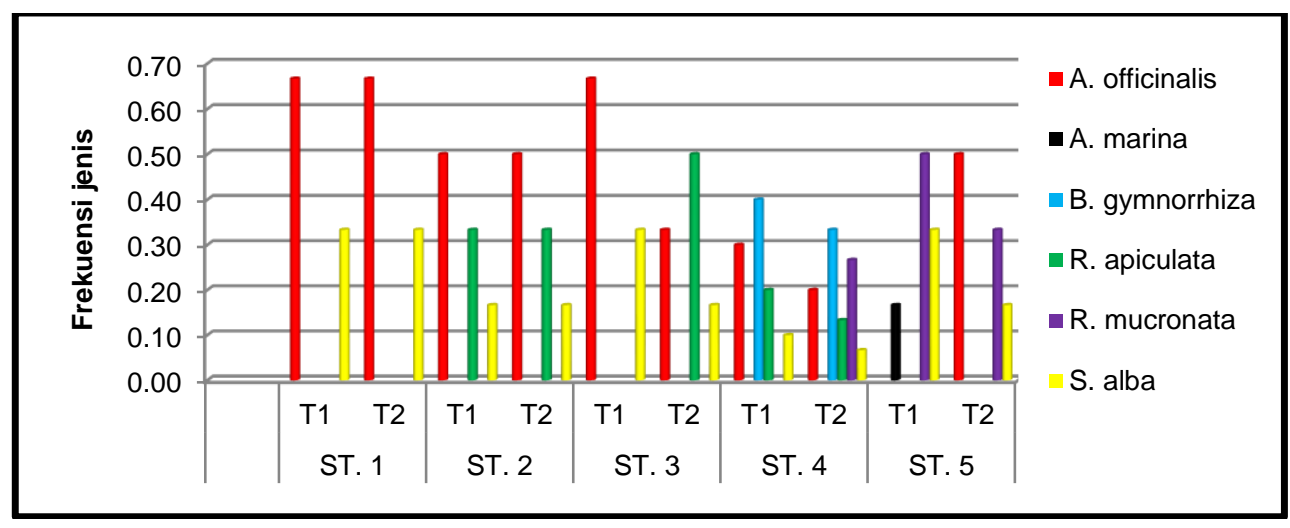

Gambar 4. Frekuensi jenis (Ket : ST : Stasiun, T : Transek)

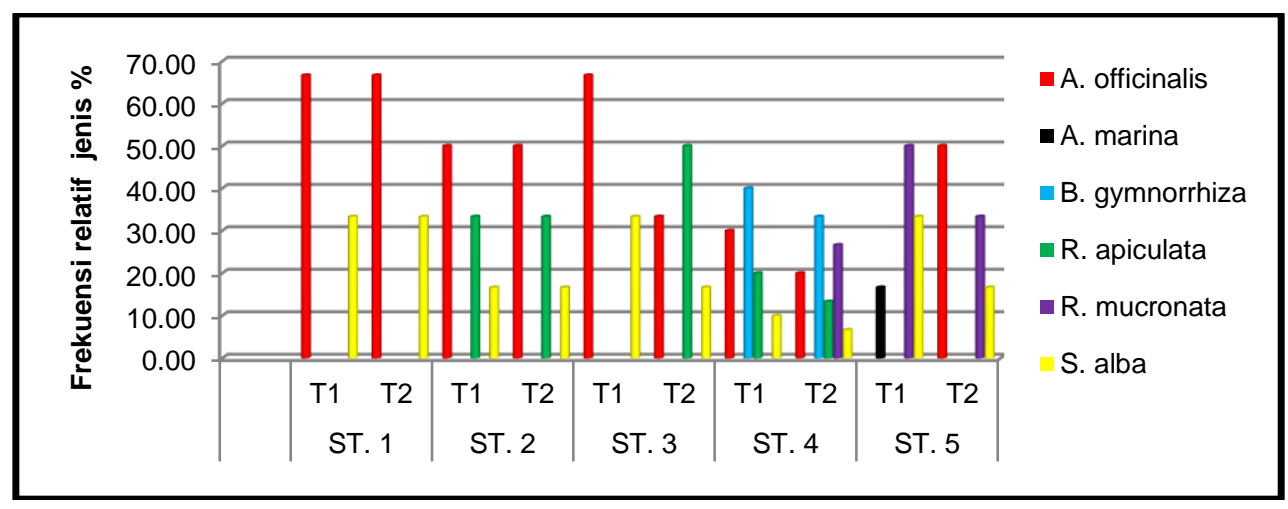

Gambar 5. Frekuensi relatif jenis (Ket : ST : Stasiun, T : Transek)

A.officinalis yaitu 0,500 , terendah di transek 1 dan 2 oleh S.alba yaitu 0,167 , sedangkan nilai frekuensi relatifnya yaitu 50,00 dan 16,67 . Nilai tertinggi frekuensi jenis pada stasiun 3 (Tongkaina) di transek 1 adalah A.officinalis yaitu 0,667 , terendah di transek 2 oleh S.alba yaitu 0,167 , sedangkan nilai frekuensi relatifnya yaitu 66,67 dan 16,67. Nilai tertinggi frekuensi jenis pada stasiun 4 (Bahowo) di transek 1 adalah B.gymnorrhiza yaitu 0,400 , terendah di transek 2 oleh S.alba yaitu 0,067, sedangkan nilai frekuensi relatifnya yaitu 40,00 dan 6,667. Nilai tertinggi frekuensi jenis pada stasiun 5 (Tiwoho) di transek 1 dan 2 adalah A.officinalis dan R.mucronata yaitu 0,500 , terendah di transek 1 dan 2 yaitu A.marina dan $S$.alba yaitu 0,167 , sedangkan nilai frekuensi relatifnya yaitu 50,00 dan 33,33 .

\section{Penutupan Jenis dan Penutupan Relatif Jenis}

Nilai tertinggi penutupan jenis pada stasiun 1 (Molas) di transek 1 adalah S.alba yaitu 16,48 , terendah di transek 1 oleh A.officinalis yaitu 7,145, sedangkan nilai penutupan relatifnya yaitu 69,75 dan 30,25. Nilai tertinggi penutupan jenis pada stasiun 2 (Meras) di transek 1 adalah S.alba yaitu 17,55, terendah di transek 1 oleh A.officinalis yaitu 1,493 , sedangkan nilai penutupan relatifnya yaitu 62,49 dan 1,493 . Nilai tertinggi penutupan jenis pada stasiun 3 


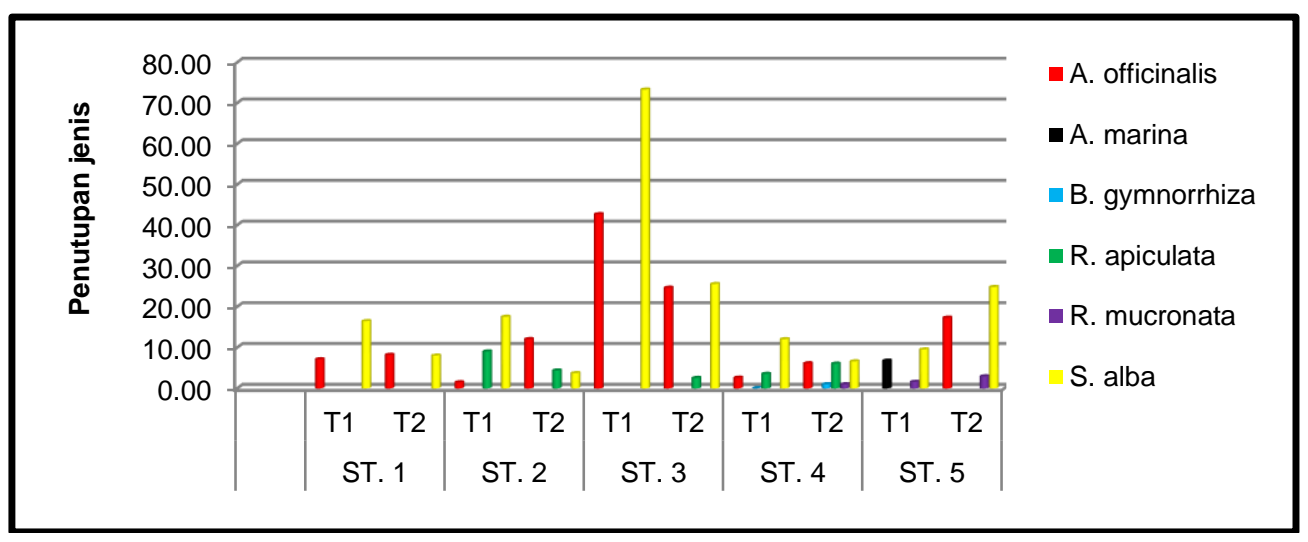

Gambar 6. Penutupan jenis (Ket : ST : Stasiun, T : Transek)

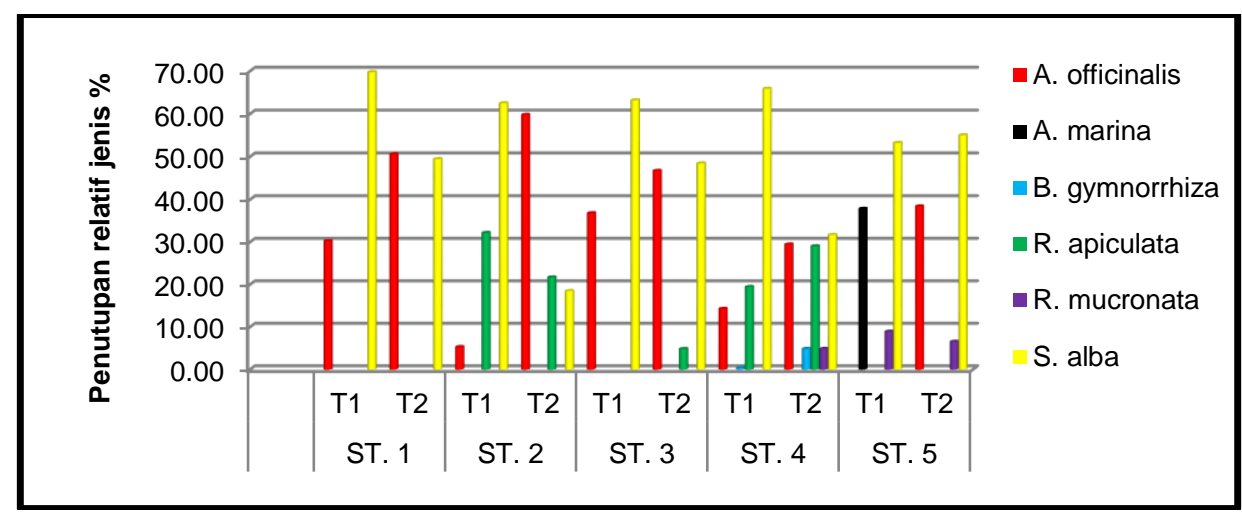

Gambar 7. Penutupan relatif jenis (Ket : ST : Stasiun, T : Transek)

(Tongkaina) di transek 1 adalah S.alba yaitu 73,29, terendah di transek 2 oleh $R$.apiculata yaitu 2,562, sedangkan nilai penutupan relatifnya yaitu 63,19 dan 4,850 . Nilai tertinggi penutupan jenis pada stasiun 4 (Bahowo) di transek 1 adalah R.apiculata yaitu adalah S.alba yaitu 12,06, terendah di transek 1 oleh B.gymnorrhiza yaitu 0,068 , sedangkan nilai penutupan relatifnya yaitu 65,88 dan 0,371 . Nilai tertinggi penutupan jenis pada stasiun 5 (Tiwoho) di transek 2 adalah S.alba yaitu 24,84 , terendah di transek 1 yaitu R.mucronata yaitu 1,604 , sedangkan nilai penutupan relatifnya yaitu 55,04 dan 8,949.

Faktor yang mempengaruhi rendahnya nilai penutupan jenis karena adanya kondisi mangrove yang heterogen. Menurut Raymond et al.
(2010), semakin heterogen jenis mangrove dalam suatu komunitas maka peranannya akan terbagi-bagi dan besarnya indeks akan semakin bervariasi.

\section{Indeks Nilai Penting}

Indeks nilai penting tertinggi pada stasiun 1 (Molas) di transek 1 adalah S.alba yaitu 178,09, terendah di transek 1 oleh A.officinalis yaitu 121,91. Indeks nilai penting tertinggi pada stasiun 2 (Meras) di transek 2 adalah A.officinalis yaitu 174,07 , terendah di transek 2 oleh S.alba yaitu 45,89. Indeks nilai penting tertinggi pada stasiun 3 (Tongkaina) di transek 1 adalah S.alba yaitu 167,95 , terendah di 


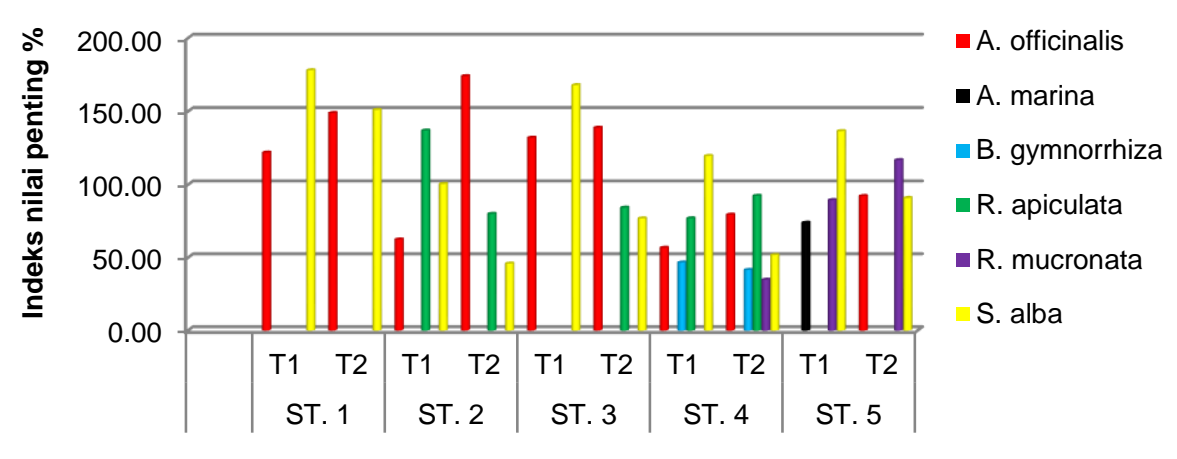

Gambar 8. Indeks nilai penting (Ket : ST : Stasiun, T : Transek)

transek 2 oleh S.alba yaitu 76,87. Indeks nilai penting tertinggi pada stasiun 4 (Bahowo) di transek 1 adalah S. alba yaitu 119,63 , terendah di transek 2 oleh R.mucronata yaitu 34,88 . Indeks nilai penting tertinggi pada stasiun 5 (Tiwoho) di transek 1 adalah S.alba yaitu 136,55 , terendah di transek 1 yaitu A.marina yaitu 73,95. Indriyanto (2006) dalam Agustini et al. (2016) berpendapat bahwa spesies-spesies yang dominan dalam suatu komunitas tumbuhan akan memiliki indeks nilai penting yang tinggi, sehingga spesies yang paling dominan akan memiliki indeks nilai penting yang paling besar.

\section{Indeks Keanekaragaman Jenis dan Indeks Kemerataan Jenis}

Nilai indek keanekaragaman jenis tertinggi terdapat pada stasiun 4 (Bahowo) di transek 2 yaitu 1,203, terendah pada stasiun 1 (Molas) di transek 1 yaitu 0,562 , sedangkan untuk nilai indeks kemerataan jenis tertinggi pada stasiun 4 (Bahowo) di transek 1 yaitu 11,14 , terendah pada stasiun 1 (Molas) di transek 2 yaitu 3,474. Menurut Indriyanto (2006)

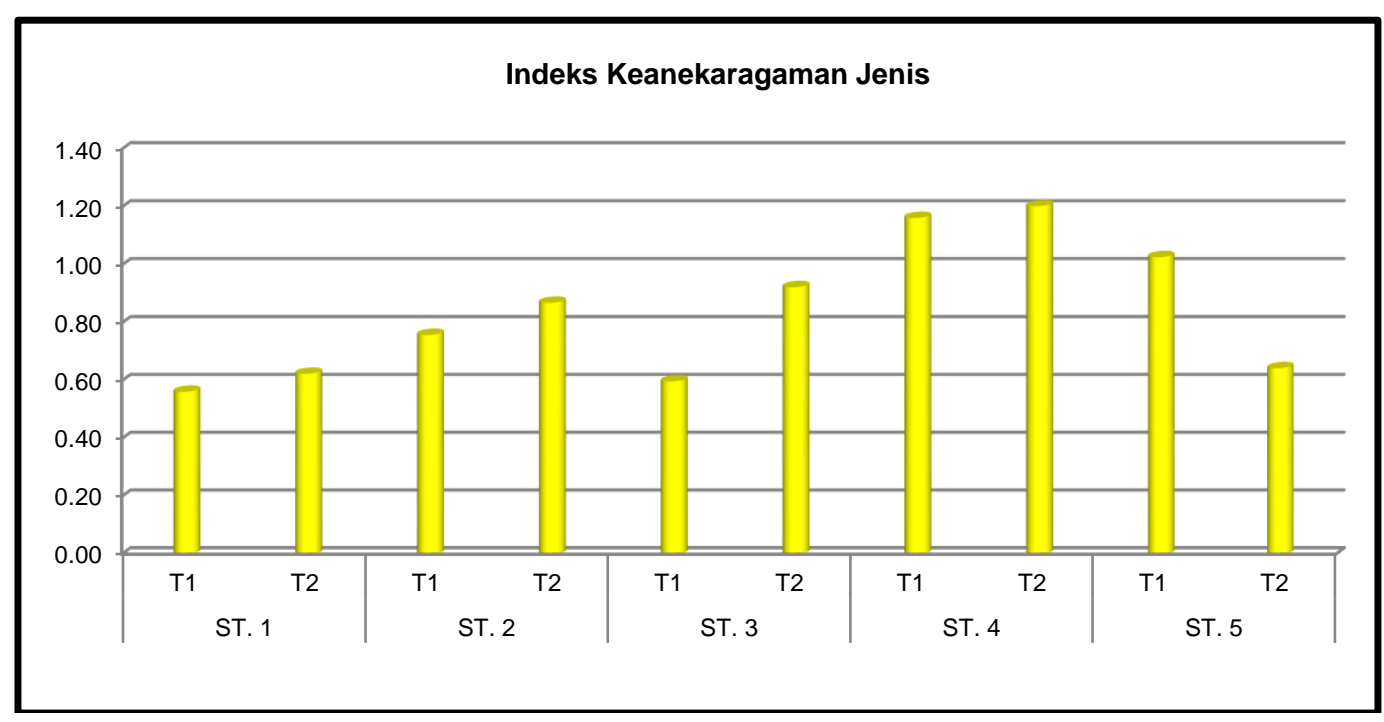

Gambar 9. Indeks keanekaragaman jenis (Ket : ST : Stasiun, T : Transek) 


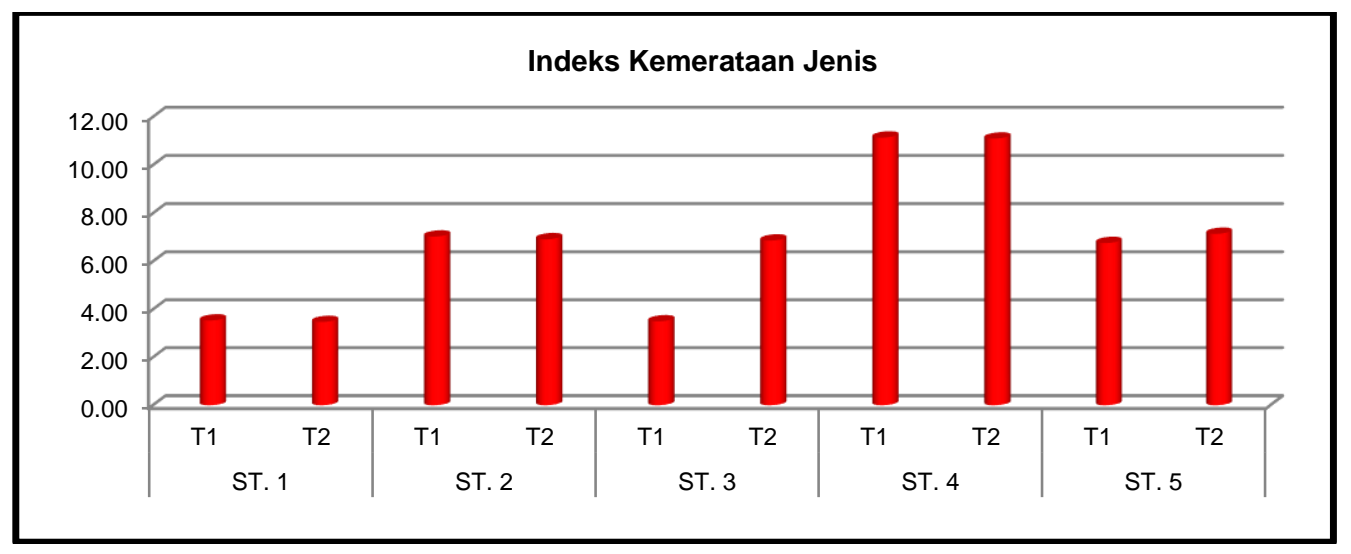

Gambar 10. Indeks kemerataan jenis (Ket : ST : Stasiun, T : Transek)

dalam Agustini et al. (2016), keanekaragaman spesies juga dapat digunakan untuk mengukur stabilitas komunitas, yaitu kemampuan suatu komunitas untuk menjaga dirinya tetap stabil.

\section{KESIMPULAN}

Dari penelitian yang dilakukan dapat disimpulkan bahwa : Nilai tutupan kanopi mangrove yang tertinggi pada stasiun 2 (Meras) di transek 2 mencapai nilai $82,78 \%$ dan yang terendah pada stasiun 1 (Molas) di transek 1 yaitu $61,24 \%$, sehingga ditinjau dari Kepmen LH No 201 Tahun 2004 tentang kriteria kerusakan mangrove termasuk pada kategori sangat padat $\geq 75 \%$ dan sedang $75 \%$.

Nilai kerapatan jenis tertinggi terdapat pada stasiun 5 (Tiwoho) di transek 2 oleh R.mucronata yaitu 0,133 ind $/ \mathrm{m}^{2}$ dan nilai kerapatan relatif yaitu $76,92 \%$, sedangkan nilai terendah pada stasiun 4 (Bahowo) di transek 2 oleh B.gymnorrhiza dan R.mucronata yaitu $0,003 \mathrm{ind} / \mathrm{m}^{2}$ dan nilai kerapatan relatif yaitu 3,333\%. Nilai frekuensi jenis tertinggi pada stasiun 1 (Molas) di transek 1 dan 2 serta stasiun 3 (Tongkaina) di transek 1 oleh A.officinalis yaitu 0,667 dan nilai frekuensi relatifnya yaitu $66,67 \%$, sedangkan nilai terendah pada stasiun 4 (Bahowo) di transek 2 oleh S.alba yaitu 0,067 dan nilai frekuensi relatifnya yaitu 6,667\%. Nilai penutupan jenis tertinggi pada stasiun 3 (Tongkaina) di transek 1 oleh S.alba yaitu 73,29 dan nilai penutupan relatifnya yaitu $63,19 \%$, sedangkan nilai terendah pada stasiun 4 (Bahowo) di transek 1 oleh B.gymnorrhiza yaitu 0,067 dan nilai penutupan relatifnya yaitu $0,371 \%$. Indeks nilai penting tertinggi pada stasiun 1 (Molas) di transek 1 oleh S.alba yaitu $178,09 \%$ dan yang nilai terendah terdapat pada stasiun 4 (Bahowo) di transek 2 oleh R.mucronata yaitu $34,88 \%$. Kemudian nilai indeks keanekaragaman jenis tertinggi pada stasiun 4 (Bahowo) di transek 2 dengan nilai yaitu 1,203 dan nilai terendahnya pada stasiun 1 (Molas) di transek 1 yaitu 0,562, sedangkan nilai indeks kemerataan tertinggi pada stasiun 4 (Bahowo) di transek 2 dengan mencapai nilai 11,14 dan nilai rendahnya pada stasiun 1 (Molas) di transek 2 yaitu 3,474.

\section{DAFTAR PUSTAKA}

Abrar, M., Giyanto., Siringoringo, R.M., Edrus, I.N., Arbi, U.Y., Sihaloho, H.F., Salatalohi, A., Sutiadi. 2014. Laporan Monitoring (Baseline) Kesehatan Ekosistem Terumbu Karang dan Ekosistem Terkait Lainnya. Taman Wisata Perairan Pulau Pieh dan Laut di sekitarnya, Provinsi Sumatera Barat. Pusat 
Penelitian Oseanografi. Lembaga Ilmu Pengetahuan Indonesia. $57 \mathrm{Hal}$.
Desa Penunggul Kecamatan Nguling Kabupaten Pasuruan. El-Hayah, 2(2): 56-63.

Agustini, N. T., Ta'aladin, Z., Purnama, D. 2016. Struktur Komunitas Mangrove Di Desa Kahyapu Pulau Enggano. Program Studi IImu Kelautan Fakultas Pertanian Universitas Bengkulu, Bengkulu. ISSN:2527-5186 Jurnal Enggano, 1(1)::19-31.

Anderson, M.C. 1964. Studies of the wood-land light climate I. The photographic computation of light condition. Journal of Ecology 52: 27-41.

Kaunang, T.D, Kimbal, J.D. 2009. Komposisi dan Struktur Vegetasi Hutan Mangrove Di Taman Nasional Bunaken Sulawesi Utara. ISSN.08525426. Agritek, Vol. 17. 9 hal.

Keputusan Menteri Negara Lingkungan Hidup No. 201 tahun 2004 tentang Kriteria Baku dan Pedoman Penentuan Kerusakan Mangrove.

Metha, A. 1999. Buku Panduan Lapangan Taman Nasional Bunaken. Balai Taman Nasional Bunaken. NRM/EPIQ Program, September 1999.

Pontoh, O. 2011. Peranan Nelayan Terhadap Rehabilitasi Ekosistem Hutan Bakau (Mangrove). Jurnal Perikanan dan Kelautan Tropis. Vol.VII-2,

Raymond, G., Harahap, N., Soenarno. 2010. Pengelolaan Hutan Mangrove Berbasis Masyarakat Di Kecamatan Gending, Probolinggo. Agritek, 18(.2):185-200.

Sofian, A., Harahab, N., Marsoedi. 2012. Kondisi Dan Manfaat Langsung Ekosistem Mangrove 